\title{
The Collaboration of SMEs through Clusters as Defense against Economic Crisis
}

\author{
Ioannis Makedos \\ Department of International and European Studies, University of Macedonia, 156 Egnatia Street, 54006 Thessaloniki, Greece \\ Correspondence should be addressed to Ioannis Makedos; john130570@gmail.com
}

Received 24 May 2014; Accepted 9 July 2014; Published 24 July 2014

Academic Editor: Junsen Zhang

Copyright ( 2014 Ioannis Makedos. This is an open access article distributed under the Creative Commons Attribution License, which permits unrestricted use, distribution, and reproduction in any medium, provided the original work is properly cited.

\begin{abstract}
The aim of this paper is to present the realistic solution to the survival problem that SMEs have during the economic crisis. The role of SMEs is very important in the development of the regional and national economy of each country, particularly for small countries like Greece. On the other hand, universities also play a significant role in the national economy, since they provide Know-How and important research in the SMEs. Nevertheless, due to their small size and financial weakness, especially on the grounds of economic crisis, SMEs would not be able to cover on their own the cost of purchase of university research. The author of this working paper suggests the collaboration of SMEs in the form of clusters so as to be able to self-fund and absorb university Know-How at the same time.
\end{abstract}

\section{Introduction}

It is a fact that if SMEs want to be competitive they must absorb all the high quality university Know-How so as to increase innovation in the production procedure, which is considered viable through the development of collaboration with universities and more specifically with their research activity. One form of this collaboration is clusters. In particular, clusters is a group of independent vehicles that take action in specific industrial or biotechnical economy-theme sectors (big enterprises or SMEs, academic institutions, and research centers) in a geographic region, with powerful interactions and exchange of information-knowledge and relative positive practices with common suppliers or/and customers, with common access to facilities, infrastructures, and services, and with the aim to gain competitive advantage in local and international level [1].

A specified conceptual approach to what is business cluster is the one of Enright and Fowcs-Williams [2] who define them as "geographical gatherings of interrelated and interconnected businesses that produce and sell a series of related products." In short, what the authors mention is that clusters can help SMEs to a great extent so as to become very competitive against big enterprises and extrovert at the same time, something that will give them a big share of the international market. In case they expand, SMEs can penetrate the field of innovation and consequently the qualitative upgrading of their production with no need to invest a great deal of money, just like large businesses.

However, it is important to examine the reason why cluster is considered necessary. Its appearance can be related to a number of positive influences, for instance, reduced business expenditure, the operation of the local market, the corresponding increased demand of products, the knowledge, the common promotion and the adoption of innovation as well as technology, the economies of scale, and the coexploitation of human fund. On the other hand, as Pyke and Sengenberger [3] mention, a small or even a medium business will find it difficult to operate autonomously in a region with developed business, in contrast to a net of businesses. The benefits that may arise for the SMEs, if they unify their powers in one cluster, are numerous and very important. The increase of competitiveness and productivity are the major advantages. This is what most researchers agree on. Also, the international bibliography mentions the development of skills of human workforce, the direct solution of problems, the exchange of information and Know-How, and low running cost. On the other hand, innovation could give significant benefits to a 
cluster, as well as to any individual business. The question is "if businesses want and can invest to innovation." Enright and Fowcs-Williams [2] claimed that regional universities, research institutions, and multiformed investments can give clusters the opportunity to invest in the field of innovation on the basis of self-funding.

In countries which are considered to be financially developed the operation of clusters is common as well as necessary [4]. But, the main researchers that developed the relative methodologies of clusters are Perroux, Porter, and Dahmen. The "landmark" for the meaning of clusters was the year 1990, when Porter published a book, giving a different dimension than the one of the traditional politicians of collaboration.

According to Ketels [1] the factors of success of a cluster are as follows:

(i) powerful focus on a geographical area with favorable business environment;

(ii) existence and creation of strategies for the improvement of the business external environment in a specific geographical area;

(iii) common opinions and strategy for commitment with the aim to achieve the original goals and the development of innovation;

(iv) effective administration and coordination of activities for the development of innovation;

(v) an even administration of the potential frictions among businesses;

(vi) exclusive availability of sponsoring of the operational cost of the initiative for the support of its administrative organization;

(vii) to ensure as many as possible private businesses.

\section{Literature Review}

The bibliography of Porter [5] provided important findings and theories about the development of clusters and highlighted their decisive contribution to the development of businesses and in particular SMEs, whilst he was the first to give an international dimension to the meaning of a cluster. He particularly stressed that businesses can selfdevelop and cooperate either with one another or with university institutions and research centres, with the objective aim to grow bigger and become international. Thus, the author of this working paper believes that SMEs can take advantage of what they have always had, that they know exactly the dynamic and the mentality of every local market, that they have an excellent network of development of the interpersonal relations with consumers, and that they know the needs of the local economy and can easily adjust to the existing conditions and necessities of the consumers.

Moreover, Piore and Sabel [6] had an important aspect on cluster. Since the 1980s they had comprehended the importance of business clusters and they highlighted the inner-business specialization of work among clusters of small enterprises, in connection with horizontal and vertical work and competitive relations and as a result the maximum improvement to the efficiency of production. Later the "Californian School" went a step ahead, claiming that business clusters can perform even better if they cooperate with universities. Specifically, he highlighted that due to a potential depletion of production funds combined to the variable course of technology, along with every negative aspect of it, businesses should on their own define their future through self-development which is directly linked to cooperation, which is clusters [7].

This aspect has had many fans since the middle 1980s until today and during this time only positive comments have been made. As usual, every notion that is developed by the international academic community is expected to confront opposite aspects. But the specific notion has not met resistance or serious reactions, something which gives it extra merit. The California School has developed the increase of new industrial posts of employment, supporting the vertical disintegration of chain productions in a new era of "flexible accumulation," leading to a respective collaboration of businesses, decreasing at the same time the corresponding business expenditures [8].

In his work "Clusters and the New Economics of Competition" Porter [5] describes in a most clear way the relations among enterprises which collaborate. This is something that gives more efficiency and makes them much more competitive. Especially, Porter defines clusters as groups of businesses with similar activity, supporting the expansion in canals and customers, as well as in manufacturers of similar complementary products and companies with similar technology.

But he was not the only one involved with clusters in the year of 1998. Padmore and Gibson [9] claimed that a cluster is a group of businesses that flourish due to mutual assistance, either through competition or through collaboration, working simultaneously as suppliers or as clients in the chain of value. Also, Lyon and Atherton [10] regarded a cluster as a collective organization in a similar business activity, gathering competitive businesses, even universities with a view to connect in a market and nonmarket way. Then, Steinle and Schiele [11] mentioned that clusters are segmental accumulations of organizations with common targets, which can achieve significant performances and promote innovation and transfer of business knowledge.

\section{The Reinforcement of SMEs through Clusters and the Role of University}

From 1998 up to 2008 Eurozone has been established as the second largest economy globally, while SMEs had a big share in this. Between 2002 and 2008 (before the universal financial crisis), the small businesses in 27 states-members of the European Union increased significantly and it turned out that they were the major source of employment posts for a big part of the European Economy, something that corresponded to 9.4 million new employment posts. Despite the fact that big businesses tended to absorb a big share of the employment and economic activity, SMEs can still operate as a major factor for the development of regional economy. 
During the last 20 years, the percentage of small businesses in the economy has increased due to the rising international competition high insecurity and technological developments. More specifically, SMEs have proved to be important vehicles of employment and fundamental factors of the innovation [12]. The emphasis on the networking of SMEs comes from the dominating trend of the previous studies that showed that SMEs are as innovative as big enterprises. In this frame, it was examined and mentioned that the best performances of SMEs are related to their capability to cooperate in a network of cluster, through exchange of information and fund raising, something which would supply them with the possibility to cover the lack of technology gap.

Bougrain and Huadeville [13] stressed that, in the countries of OECD, the policy for innovation had shifted from the direct funding to the promotion of cooperation bonds among businesses, like the reinforcement of relations with university and research institutions. The surveys that examined the bond between the collaboration and innovation of companies were based on the binary variables, so as to show whether companies collaborate or not and what their result is. For instance, in a survey 435 SMEs in a western region of the United Kingdom (2002) there was a positive connection among businesses that collaborate with the product innovation. Moreover, when the variable of production was the innovative procedure, the very same collaboration with the suppliers was significant. Also, Freel and Harrison conducted the biggest regional survey [14] for more than 1,300 SMEs from all fields of manufacturing and services in North England and Scotland. In this survey, the result was clear and mentioned the multiple benefits that arise from the collaboration of SMEs in the field of innovation. Similarly, in a survey of the industrial areas in Valencia Spain, Molina-Morales and Martínez-Fernández [15] realised that the most innovative companies were differentiated from the least innovative rivals in their ability to take part in the exchange of funds and to promote their common reputation. In a more recent survey [16] using the same data, these researchers realised that other social fundamental variables, including trust measures, social infrastructure, or common vision, were positively associated with innovation [16].

On the other hand, according to Porter [5], when a cluster of SMEs develops, then it is an example of development of new SMEs around this. That means that the cluster itself is a means of attraction to the new generation of entrepreneurship. This form of development can in turn bring new sponsors. It is a fact that universities globally have contributed greatly to the development of clusters for many decades, even before specified strategies were introduced [17].

Through university research programs many sources of support for the business clusters arise. So, the importance of universities as a judgmental element of the developing economies has successfully been highlighted, discussed, and realised [18]. The financial impact of universities is very important, mostly through university research, for local businesses and economies [19]. The infusion of knowledge creates a very favorable business environment for the development of innovation, within the boundaries of clusters.
The regional economies that rely on the development of clusters show respective improvement, according to many researchers [4]. Whilst universities institutions cannot in advance be a basic requirement for the development of clusters of SMEs [20], their significant role in the regional economic development, through the support they provide for clusters, has been confirmed and supported by many researchers [21-23].

Universities can be the source of new knowledge and invention that can support innovation, access specified laboratories, and support the business spirit and clusters, as a specialised form of business. These institutions have at times supported the creation of clusters and specifically with the participation of SMEs, even when they did not play a basic role in their mission. Furthermore, a number of universities encourage the establishment of diplomas of license, transfer knowledge, and help in every way the organisation SMEs in clusters [24].

Universities mostly focus on rapid innovative business fields but they often boast traditional fields as well. There are many examples of clusters that have been supported by universities, such as the cluster of nanotechnology in Grenoble [21], Silicon Valley, that was supported by three top universities, the cluster of Boston that was supported by MIT, the biotechnological cluster of Vienna that was based on five universities [25], and the cluster of biotechnology and computing of the wider region of Oxford that was supported by three universities [26]. A big university can negotiate and produce innovation through the specific cluster, just like Wisconsin, with research expenditure (2009) that came up to 952 million dollars, supporting the respective biomedical business cluster [20].

In April 2012 there was an announcement by the European Union of a series of new initiatives with the aim to help the extraversion of SMEs, which is to go international. These initiatives included new plans of the European Committee so as to support SMEs clusters in the fields of clean technologies renewable sources of energy, biotechnology, and sports items. In this way these businesses could benefit from their advantages through the corresponding development, in the specific fields of activity, in Asia, Latin America, North America, and Russia.

Clusters provide a healthy business environment for enterprises, especially for SMEs, and help them collaborate with research foundations and suppliers that are in the same geographical area. There is a number of clusters in Europe, more than 1,400 according to the data about the year 2014 [27] and respective organisation of collaborative formations, from which 495 have signed the European Platform of Collaboration of Cluster.

\section{Cluster, a "Shield" against Financial Crisis}

From the moment a cluster achieves to develop it starts to connect with external associates. In particular, it makes deals with specialized suppliers at a lower cost and evaluates the sales, so as to satisfy the needs and desires of consumers. In this way, a cluster expands and establishes itself in the market. Then, by taking advantage of its comparative advantages, 
through the exchange of Know-How and the development of innovation it can become extremely competitive and viable towards the big businesses of the same field. When clusters become competitive they can make deals with universities for the exclusive exploitation of their technical knowledge, so as to obtain specialised staff and knowledge, something that SMEs cannot have on their own, due to the big cost. On the other hand, the State can play an important role, as it would be able to invest to new research centers and universities about clusters, according to the rationale of scientific parks, thus facilitating the work of the SMEs that take part in these [28].

As mentioned above, a cluster can deal with a period of financial crisis. The goal is to avoid all these mistakes that could lead a cluster to a crisis. In particular, due to the rapid development of clusters, there is a possibility of self-scorn only in case they do not adopt innovation and the progress of technology. Because there will be another company or even cluster that will not make the same mistake and will replace the former through innovation. Another reason of the descending way of a cluster is the continuous conflicts and the big competition among businesses that are part of it. In other words, the avoidance of intense and continuous friction, the comprehension of the work and operation of every business participant, and the understanding that every member of a cluster is necessary for its existence can altogether deter a negative evolution.

A different study but with equally useful conclusions was that of Hagen et al. [29], which mentioned that one of the advantages of cluster from which they can benefit so as to obtain a big circle of life is extraversion, which is the internationalisation of their activities. After they had examined four clusters of different strategies, they realised the positive association and efficiency, coming to the conclusion that the cluster which has more export activity expands faster, increases directly its performance, and achieves easily its original goals. Additionally, this research mentioned that another important factor that can expand the activities of a cluster, improve its performance, and thus its viability is to firmly follow the original strategies (except under unpredicted financial conditions) and combine them with direct decision making.

\section{The Total Benefits Clusters Bring about}

The financial activity that comes from the operation of SMEs within the boundaries of a cluster leads to direct advantages, like low production cost (including exchange expenditures), flexibility depending on the high mobility of the workforce and resources, and penetration in the field of innovation (i.e., knowledge spillover). The role of clusters in the financial enlargement has been elaborated on many studies and surveys for many years. For instance, according to the data of the Observatory for European Clusters [27], the author of this working paper has come to the conclusion that the economic well-being among different European regions is directly associated with the degree of power of clusters in a respective relationship.

The data reveal that innovation and economic growth are two factors that are directly linked to powerful clusters, as they provide a business environment with the direction of innovation and knowledge infusion. Areas with powerful briefcase clusters are presented as leaders in the market whilst on the contrary the regions that do not have clusters show a decrease in the field of economy and business development. Also, another basic feature that is included in the field of clusters is that rivalry coexists with free market and entrepreneurship.

Innovation shows a high degree of infusion within and out of boundaries of countries during the last decade, as there have been a great number of empirical studies about the association of European regions and innovative action that have been published [30]. Also, the data of the Observatory for European Clusters show a significant connection between regional specialisation and the innovative performance. European regions without clusters showed economic malfunction, underdevelopment, and generally deindustrialisation. On the contrary, regions with powerful clusters showed significant economic development, apart from some very few exceptions.

All these highlight that the economic activity of a region depends not only on the degree of specialisation but also on other elements of the wider microeconomic environment, like work quality, research and education, their connection with SMEs cluster, and access to the fund and advanced infrastructure. Regions with active and powerful clusters (especially SMEs) are more efficient obviously in the sector of innovation. A healthy inner competition might be necessary, as it accounts for the successful operation of the regional economy, as, for instance, the high degree of urbanization, creating a favorable business environment as long as there are university institutions in an area nearby [31].

On the other hand, according to the data of the European Cluster Observatory [27] based on the average of efficiency of innovation, the countries members of the European Union are categorized in four groups of dynamic (Figure 1). The first is called "Innovation Leader" where Denmark, Germany, Finland, and Sweden belong, as they have shown at least 20\% higher degree of innovation than the average of Europe. These countries have complete multidimensional balanced systems of innovation with the respective advantages.

Next is the group "Innovation Followers" (between 10\% and $20 \%$ higher degree of innovation than the European average) that consists of Luxemburg, Holland, Belgium, UK, Ireland, Austria, France, Slovenia, Estonia, and Cyprus. From these countries, only the last three, Slovenia, Estonia, and Cyprus, present an efficiency of innovation smaller than the European average.

In the group "Moderate Innovators" (between 50\% and 90\% than the total performance of the E.U-27) is Greece, along with Italy, the Czech Republic, Spain, Portugal, Hungary, Slovakia, Malta, Croatia, and Lithuania. In the last place we have the group "Modest Innovators" (less than 50\% than the average performance of innovation of the E.U.-27) with Bulgaria, Latvia, Romania, and Poland.

We must mention that the previous categorization concerns the total performance of the innovation systems of the countries. But there are some countries that stand out mostly in the innovation performance in fields. Specifically, 


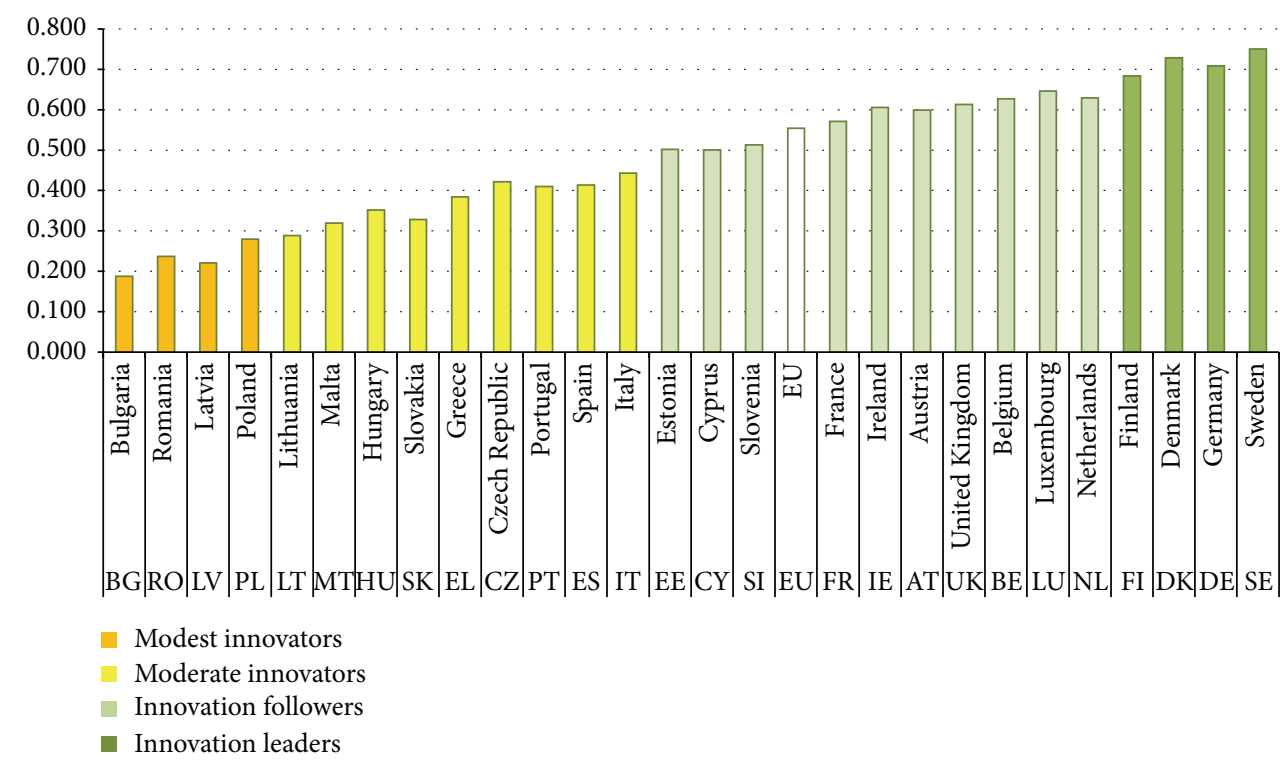

FIGURE 1: EU Member States' innovation performance. Source: Innovation Union Scoreboard 2013.

Sweden, Finland, the UK, and Ireland are considered successful in the field of human resources, while Denmark, Holland, Sweden, and the United Kingdom in the open and effective systems of research. Moreover, Finland, Estonia, Denmark, and Sweden present the best performances of innovation in the fields of sponsoring and support, while Sweden, Germany, Slovenia, and Finland in the field of business investments. On the other hand, Denmark, Belgium, Sweden, and the UK are pioneer countries in the field of connections and entrepreneurship, while Austria, Germany, Denmark, and Sweden in the field of loyalties. Basically, the annual average pace of development in the performance in the field of innovation has come up to $1.7 \%$ during 20062013, while all the countries ameliorated their performances (from little to more) in innovation. Estonia, Latvia, and Portugal presented the highest percentages in the pace of development, whilst the lowest were of the UK, Sweden, and Croatia.

SMEs, as well as very small enterprises, can support the subsequent evolution and their reinforcement if they enter a cluster, according to what modern bibliography and empirical study mention. According to Libaers and Meyer [32], upon entering a cluster, the dynamic of SMEs multiplies and they can take better advantage of the resources in comparison to those of the SMEs that try to operate autonomously. They have examined how heterogeneity in the level of technological competition or investments in Research and Development among companies that operate within clusters affect the improvement of performance and the gathering of profits that arise for them as well as for local economies. As they mentioned in their research, the level of development of clusters is positively associated to the degree of globalization and extraversion of the SMEs, as in the degree of innovation.

\section{Research Methodology and Analysis Data}

The aim of this working paper is to present realistic solutions for the survival problem firstly and for the economic growth secondly, for the Small and Medium Enterprises (SMEs), especially in the period of the economic crisis in smaller countries, like Greece. The research took place through survey data which were collected from 113 Greek companies. Especially, the personal interviews were held with the owners or managers of the enterprises. Also, the data collection was realized from February 2013 up to August 2013. First the data were entered and coded in Excel and later imported into SPSS 22.00 for further descriptive analysis. The sample was based on quota basis, but not at random choice, since the enterprises were selected with determined criteria, like the following:

(i) the size of the company;

(ii) the geographical area of companies;

(iii) the companies' data before and after the economic crisis.

According to Kinnear and Taylor [33] the three basic types of the research are exploratory, deductive, and experimental. The author used the exploratory type of research since the aim is the verification of the problems, for the hierarchy of priorities. The collection of data was realized with the method of personal interviews, with the use of structure questionnaire, following the important criteria of validity and reliability. This method has the big advantage which makes it possible to reject comprehension of questions from the interviewers which would lead to erroneous conclusions and erroneous results [34].

The nonrandom choice of the sample has the important advantage that the enterprises which were selected can give greater value to the results of the analysis of the survey data. 
TABLE 1: Respondent results from questionnaire survey.

\begin{tabular}{lcc}
\hline Hypothesis & $\begin{array}{c}\text { Answer "yes" of } \\
\text { SMEs }\end{array}$ & $\begin{array}{c}\text { Answer "yes " of large } \\
\text { companies }\end{array}$ \\
\hline SMEs are important in the national economy of any country & 47 & 16 \\
SMEs are important in national economy of small countries, like Greece & 49 & 19 \\
The university research is necessary for any company & 30 & 13 \\
The university research is necessary for the SMEs & 31 & 21 \\
SMEs can be stronger if they apply the university research in the market & 18 & 6 \\
SMEs can be competitive to large enterprises & 41 & 42 \\
SMEs can be competitive to large enterprises in the period of crisis & 40 & 13 \\
The role of clusters is important & 37 \\
The role of clusters of SMEs is important & 13 \\
The clusters of SMEs can be competitive against large enterprises & 13 \\
With the clusters the SMEs can be stronger and self-funding against economic crisis & 42 \\
\hline
\end{tabular}

Also, it was preferable that the questionnaires be completed by the owners or directors of enterprises, people that are directly involved in the strategy planning and their answers can have high quality data for further analysis.

In the questionnaire two types of questions were included, open and closed. With the open ones the opinions can be developed and with the closed questions we allow the use of quantitative analyses and to make comparable the answers between asked groups. Also, the author used the bisecting questions; this gives the choice as one of two answers, since the target was to create an evident questionnaire.

\section{Results and Discussion}

From the sample of 113 enterprises (77 SMEs and 36 large companies), 75 of them (or else $66.37 \%$ ) answered correctly. Out of 75 enterprises, 24 were large companies (32\%) and 51 SMEs (68\%). According to Hamilton [35], this percentage is very successful, following the standards of high quality of survey.

Table 1 shows the percentage of responses from SMEs and large enterprises from the questionnaire survey. In the question "if SMEs are important in the national economy of any country," $92 \%$ of SMEs and $68 \%$ of large companies answered "yes," while $97 \%$ of SMEs and $78 \%$ of large enterprises believe that "SMEs are important for the national economy of small countries, like Greece." From this data it is obvious that the role of SMEs in any country, and especially in smaller countries (like Greece), is very important for their national economy. That is what not only SMEs but also large companies believe.

On the other hand, the value of university research is not so big for any company, according to the answers of SMEs $(51 \%)$ in opposition to large companies (62\%). But most SMEs $(59 \%)$ believe that university research is more necessary for them (59\%) than what large companies believe (53\%). Also, $61 \%$ of SMEs answered positively in the hypothesis "SMEs can be stronger if they apply the university research in the market," something that large companies (53\%) do not agree so much with. That means that there is margin for the SMEs to understand that the university research can be a vehicle to their economic growth, something that is not so sure according to the large enterprises.

Moreover, SMEs (42\%) believe more than large enterprises $(25 \%)$ that "SMEs can be competitive against large enterprises," while $65 \%$ of SMEs and $82 \%$ of large companies believe that the factor of economic crisis can hit mostly the SMEs. From this data we can conclude that the economic crisis is a factor that first hits the SMEs and later the larger companies, and for this reason SMEs must find directly a solution to their survival problem.

Also, the important role of clusters is accepted by $81 \%$ of SMEs and $74 \%$ of large enterprises, since the role of SMEs clusters is more important for the SMEs (83\%) than for the large companies (66\%). The answers of SMEs (79\%) showed that they support the solution of clusters of SMEs which can be competitive against large enterprises, in contrast to the answers of large enterprises (52\%) that they believe less in this solution. The meaning of this data is very important, because we can see clearly that SMEs have understood that when they collaborate through clusters they can be competitive against large enterprises. Finally, 73\% of SMEs believe that "with the clusters the SMEs can be stronger and self-funding against economic crisis" and only 51\% of large enterprises are of the same opinion. Especially, during the period of the economic crisis, SMEs believe that with the solutions of clusters they can be self-funding and they do not need to wait for the help of the State. And the answers of large companies (more than half, $52 \%$ ) show the same.

After statistical analysis, as illustrated in Table 2, SMEs can be stronger with university research in the real market according to $31 / 51$ SMEs $(60.8 \%)$. Also, Fisher's exact test (0.000) showed that there is big association between the stronger SMEs and the application of university research (from SMEs) in real market.

As illustrated on Table 3, 13/24 large companies (54.16\%) believe that SMEs can be stronger if they apply the university research in real market. The Pearson Chi-Square Test 
TABle 2: Answers of SMEs "if SMEs can be stronger with the university research."

\begin{tabular}{|c|c|c|c|}
\hline \multicolumn{4}{|c|}{ Stronger SMEs $*$ university research cross-tabulation } \\
\hline & \multicolumn{2}{|c|}{ University research } & \multirow{2}{*}{ Total } \\
\hline & No & Yes & \\
\hline \multicolumn{4}{|l|}{ Stronger SMEs } \\
\hline \multicolumn{4}{|l|}{ No } \\
\hline Count & 17 & 3 & 20 \\
\hline$\%$ within stronger SMEs & $85.0 \%$ & $15.0 \%$ & $100.0 \%$ \\
\hline$\%$ within university research & $85.0 \%$ & $9.7 \%$ & $39.2 \%$ \\
\hline$\%$ of total & $33.3 \%$ & $5.9 \%$ & $39.2 \%$ \\
\hline \multicolumn{4}{|l|}{ Yes } \\
\hline Count & 3 & 28 & 31 \\
\hline$\%$ within stronger SMEs & $9.7 \%$ & $90.3 \%$ & $100.0 \%$ \\
\hline$\%$ within university research & $15.0 \%$ & $90.3 \%$ & $60.8 \%$ \\
\hline$\%$ of Total & $5.9 \%$ & $54.9 \%$ & $60.8 \%$ \\
\hline \multicolumn{4}{|l|}{ Total } \\
\hline Count & 20 & 31 & 51 \\
\hline$\%$ within stronger SMEs & $39.2 \%$ & $60,8 \%$ & $100.0 \%$ \\
\hline$\%$ within university research & $100.0 \%$ & $100.0 \%$ & $100.0 \%$ \\
\hline$\%$ of total & $39.2 \%$ & $60.8 \%$ & $100.0 \%$ \\
\hline
\end{tabular}

TABLE 3: Answers of large companies "if SMEs can be stronger with university research."

\begin{tabular}{|c|c|c|c|}
\hline \multicolumn{4}{|c|}{ Stronger SMEs $*$ university research cross-tabulation } \\
\hline & \multicolumn{2}{|c|}{ University research } & \multirow{2}{*}{ Total } \\
\hline & No & Yes & \\
\hline \multicolumn{4}{|l|}{ Stronger SMEs } \\
\hline \multicolumn{4}{|l|}{ No } \\
\hline Count & 9 & 2 & 11 \\
\hline$\%$ within stronger SMEs & $81.8 \%$ & $18.2 \%$ & $100.0 \%$ \\
\hline$\%$ within university research & $81.8 \%$ & $15.4 \%$ & $45.8 \%$ \\
\hline$\%$ of total & $37.5 \%$ & $8.3 \%$ & $45.8 \%$ \\
\hline \multicolumn{4}{|l|}{ Yes } \\
\hline Count & 2 & 11 & 13 \\
\hline$\%$ within stronger SMEs & $15.4 \%$ & $84.6 \%$ & $100.0 \%$ \\
\hline$\%$ within university research & $18.2 \%$ & $84.6 \%$ & $54.2 \%$ \\
\hline$\%$ of total & $8.3 \%$ & $45.8 \%$ & $54.2 \%$ \\
\hline \multicolumn{4}{|l|}{ Total } \\
\hline Count & 11 & 13 & 24 \\
\hline$\%$ within stronger SMEs & $45.8 \%$ & $54.2 \%$ & $100.0 \%$ \\
\hline$\%$ within university research & $100.0 \%$ & $100.0 \%$ & $100.0 \%$ \\
\hline$\%$ of total & $45.8 \%$ & $54.2 \%$ & $100.0 \%$ \\
\hline
\end{tabular}

$(0.001<0.1)$ implies that the application of university research in real market is not indifferent to the creation of stronger SMEs.

As illustrated in Table 4, Fisher's exact test (0.000) implies that there is strong association between clusters of SMEs and competitiveness against large companies. Especially, 40/51 answers of SMEs (78.43\%) show that if the SMEs collaborate in clusters they can be competitive against large companies.
As we can see from Table 5, 13/24 large companies (54.16\%) answered that clusters of SMEs can be competitive against large companies. The Pearson Chi-Square Test $(P$ value $0.001<0.1$ ) implies that the factor of clusters of SMEs is not indifferent to the factor of competitive ness against large companies.

\section{Conclusions}

In order to find survival solutions for the SMEs especially in small countries (like Greece) and despite the economic crisis a research was carried out through questionnaire survey. From the sample of 113 enterprises the response rate was $66.37 \%$ (75 companies) which according to international bibliography is very important. The findings indicate that SMEs have the choice of collaboration through clusters against crisis. Especially, they can find the way to have access to university research to apply it in the real market. This proposal is not only applicable but also necessary, especially due to the negative financial circumstances. Especially, SMEs that were in the centre of the financial crisis from the beginning should find ways of self-development and selfsponsoring, without expecting any financial support from the State. It has been concluded that when SMEs collaborate with universities, they can have competitive advantages and establish their position in the international entrepreneurship.

Additionally, SMEs can understand that university research can be development "booster," and during the period of economic crisis they can find directly the solution to their survival problem. Also, when SMEs collaborate through clusters, they can be competitive to large enterprises. The statistical analysis illustrated that there is strong association between stronger SMEs and application of university research in real market. Additionally, there is strong association between clusters of SMEs and competitiveness against large companies.

Directions for further research are the ways that SMEs can reduce their cost through the increase of their innovation in the productive process. In particular, the research reveals that the collaboration between SMEs in the form of clusters is applicable and necessary; so as to fortify their fund base and be able to purchase university Know-How and research that will increase their chances of viability, significant profits, and further development. The collaboration of SMEs, through clusters, was combined with top quality innovation and it has been confirmed that a big number of empirical studies has been associated with the increase of innovation in regions where clusters of SMEs operated. This is proven by the data of the European Observatory for Clusters in combination with the econometric analysis, as they present a significant correlation between regional specialization (degree of cluster gathering) and innovative performance (estimated in a level of consolidation of patents). On the contrary, regions without clusters presented economic malfunction, underdevelopment, and generally deindustrialization.

Clusters have been a realistic and tested solution in the international entrepreneurship for decades (1980 onwards) with excellent results. Concisely, what the international bibliography mentions is that clusters may help greatly SMEs so 
TABLE 4: Answers of SMEs “if the clusters of SMEs can be competitive against large enterprises."

Clusters of SMEs $*$ competitive against large companies cross-tabulation

Competitive against large companies

No

Yes

Total

\begin{tabular}{|c|c|c|c|}
\hline \multicolumn{4}{|l|}{ Clusters of SMEs } \\
\hline \multicolumn{4}{|l|}{ No } \\
\hline Count & 9 & 2 & 11 \\
\hline$\%$ within clusters of SMEs & $81.8 \%$ & $18.2 \%$ & $100.0 \%$ \\
\hline$\%$ within competitive against large companies & $81.8 \%$ & $5.0 \%$ & $21.6 \%$ \\
\hline$\%$ of total & $17.6 \%$ & $3.9 \%$ & $21.6 \%$ \\
\hline \multicolumn{4}{|l|}{ Yes } \\
\hline Count & 2 & 38 & 40 \\
\hline$\%$ within clusters of SMEs & $5.0 \%$ & $95.0 \%$ & $100.0 \%$ \\
\hline$\%$ within competitive against large companies & $18.2 \%$ & $95.0 \%$ & $78.4 \%$ \\
\hline$\%$ of total & $3.9 \%$ & $74.5 \%$ & $78.4 \%$ \\
\hline \multicolumn{4}{|l|}{ Total } \\
\hline Count & 11 & 40 & 51 \\
\hline$\%$ within clusters of SMEs & $21.6 \%$ & $78.4 \%$ & $100.0 \%$ \\
\hline$\%$ within competitive against large companies & $100.0 \%$ & $100.0 \%$ & $100.0 \%$ \\
\hline$\%$ of total & $21.6 \%$ & $78.4 \%$ & $100.0 \%$ \\
\hline
\end{tabular}

TABLE 5: Answers of large companies "if the clusters of SMEs can be competitive against large enterprises."

\begin{tabular}{|c|c|c|c|}
\hline \multicolumn{4}{|c|}{ Clusters of SMEs $*$ competitive against large companies cross-tabulation } \\
\hline & \multicolumn{2}{|c|}{ Competitive against large companies } & \multirow{2}{*}{ Total } \\
\hline & No & Yes & \\
\hline \multicolumn{4}{|l|}{ Clusters of SMEs } \\
\hline \multicolumn{4}{|l|}{ No } \\
\hline Count & 9 & 2 & 11 \\
\hline$\%$ within clusters of SMEs & $81.8 \%$ & $18.2 \%$ & $100.0 \%$ \\
\hline$\%$ within competitive against large companies & $81.8 \%$ & $15.4 \%$ & $45.8 \%$ \\
\hline$\%$ of total & $37.5 \%$ & $8.3 \%$ & $45.8 \%$ \\
\hline \multicolumn{4}{|l|}{ Yes } \\
\hline Count & 2 & 11 & 13 \\
\hline$\%$ within clusters of SMEs & $15.4 \%$ & $84.6 \%$ & $100.0 \%$ \\
\hline$\%$ within competitive against large companies & $18.2 \%$ & $84.6 \%$ & $54.2 \%$ \\
\hline$\%$ of total & $8.3 \%$ & $45.8 \%$ & $54.2 \%$ \\
\hline \multicolumn{4}{|l|}{ Total } \\
\hline Count & 11 & 13 & 24 \\
\hline$\%$ within clusters of SMEs & $45.8 \%$ & $54.2 \%$ & $100.0 \%$ \\
\hline$\%$ within competitive against large companies & $100.0 \%$ & $100.0 \%$ & $100.0 \%$ \\
\hline$\%$ of total & $45.8 \%$ & $54.2 \%$ & $100.0 \%$ \\
\hline
\end{tabular}

as to be extremely competitive against large businesses, to acquire extraversion that will give them an important share of the global market and at the same time to develop significant innovation, which may be the most basic factor of survival nowadays.

\section{Conflict of Interests}

The author declares that there is no conflict of interests regarding the publication of this paper.

\section{References}

[1] C. Ketels, The Development of the Cluster Concept-Present Experiences Andfurther Developments, Harvard Business School, Harvard, Mass, USA, 2003.

[2] M. Enright and I. F. Fowcs-Williams, "Local partnership, clusters and SMEG lobalization," in Proceedings of the Conference for Ministers responsible for SMEs and Industry Ministers, Bologna, Italy, 2000.=

[3] F. Pyke and W. Sengenberger, Industrial Districts and Local Economic Regeneration, International Institute of Labour Studies, Geneva, Switzerland, 1992. 
[4] O. Solvell, G. Lindqvist, and C. Ketels, The Cluster Initiative Greenbook, The Competitiveness Institute (TCI), Vinnova, Gothenburg, Sweden, 2003.

[5] M. E. Porter, "Clusters and the new economics of competition," Harvard Business Review, vol. 76, no. 6, pp. 77-90, 1998.

[6] M. J. Piore and C. F. Sabel, The Second Industrial Divide. Possibilities for Prosperity, Basic Books, New York, NY, USA, 1984.

[7] P. Piperopoulos and G. Piperopoulos, "Is Greece finally on the right path toward entrepreneurship, innovation, and business clusters?" International Journal of Public Administration, vol. 33, no. 1, pp. 55-59, 2010.

[8] A. J. Scott, "Flexible production systems and regional development: the rise of new industrial spaces in North America and western Europe," International Journal of Urban and Regional Research, vol. 12, no. 2, pp. 171-186, 1988.

[9] T. Padmore and H. Gibson, "Modelling systems of innovation: II. A framework for industrial cluster analysis in regions," Research Policy, vol. 26, no. 6, pp. 625-641, 1998.

[10] F. Lyon and A. Atherton, A Business View of Clustering: Lessons for Cluster Development Policies. Foundation for SME Development, University of Durham, Durham, UK, 2000.

[11] C. Steinle and H. Schiele, "When do industries cluster? A proposal on how to assess an industry's propensity to concentrate at a single region or nation," Research Policy, vol. 31, no. 6, pp. 849-858, 2002.

[12] E. Santarelli and M. Vivarelli, "Entrepreneurship and the process of firms' entry, survival and growth," Industrial and Corporate Change, vol. 16, no. 3, pp. 455-488, 2007.

[13] F. Bougrain and B. Haudeville, "Innovation, collaboration and SMEs internai research capacities," Research Policy, vol. 31, no. 5, pp. 735-747, 2002.

[14] M. S. Freel and R. T. Harrison, "Innovation and cooperation in the small firm sector: evidence from 'Northern Britain," Regional Studies, vol. 40, no. 4, pp. 289-305, 2006.

[15] F. X. Molina-Morales and M. T. Martínez-Fernández, "Factors that identify industrial districts: an application in Spanish manufacturing firms," Environment and Planning A, vol. 36, no. 1, pp. 111-126, 2004.

[16] F. X. Molina-Morales and M. T. Martínez-Fernández, "Social networks: effects of social capital on firm innovation," Journal of Small Business Management, vol. 48, no. 2, pp. 258-279, 2010.

[17] F. J. Calzonetti, D. M. Miller, and N. Reid, "Building both technology-intensive and technology-limited clusters by emerging research universities: the Toledo example," Applied Geography, vol. 34, no. 1, pp. 265-273, 2011.

[18] P. Benneworth and G. Hospers, "The new economic geography of old industrial regions: universities as global-local pipelines," Environment and Planning C: Government and Policy, vol. 25, no. 6, pp. 779-802, 2007.

[19] J. Drucker and H. Goldstein, "Assessing the regional economic development impacts of universities: a review of current approaches," International Regional Science Review, vol. 30, no. 1, pp. 20-46, 2007.

[20] M. Kenney, S. Nelson, and D. Patton, "Reconsidering the Bayh-Dole Act and the current university invention ownership model," Research Policy, vol. 38, no. 9, pp. 1407-1422, 2009.

[21] J. Potter and G. Miranda, Eds., Clusters, Innovation and Entrepreneurship, OECD, 2009.

[22] S. Yusuf and S. K. Nabeshima, How Universities Promote Economic Growth, The World Bank, Directions in Development, Washington, DC, USA, 2007.
[23] M. S. Gertler, "Rules of the game: the place of institutions in regional economic change," Regional Studies, vol. 44, no. 1, pp. $1-15,2010$.

[24] P. Braunerhjelm and C. Helgesson, "The emergence of a European biotechnology cluster: the case of Medicon Valley," in Cluster Genesis, P. Braunerhjelm and F. Maryann, Eds., Oxford University Press, Oxford, UK, 2006.

[25] F. Todtling and M. Trippl, "The biotechnology cluster of Vienna," in Clusters, Innovation and Entrepreneurship, J. Potter and G. Miranda, Eds., pp. 103-130, OECD, 2009.

[26] H. Lawton-Smith, "The high-tech cluster of Oxfordshire, United Kingdom," in Clusters, Innovation and Entrepreneurship, J. Potter and G. Miranda, Eds., pp. 73-102, OECD, 2009.

[27] Cluster Observatory, "Strong Clusters in innovative Regions," 2014, http://www.clusterobservatoryry.eu/common/galleries/ downloads/Strong_Clusters_in_Innovative_Regions_Report.pdf.

[28] P. Herbig and J. E. Golden, "How to keep that innovative spirit alive. An examination of evolving innovative hot spots," Technological Forecasting and Social Change, vol. 43, no. 1, pp. 75-90, 1993.

[29] B. Hagen, A. Zucchella, P. Cerchiello, and N. de Giovanni, "International strategy and performance-clustering strategic types of SMEs," International Business Review, vol. 21, no. 3, pp. 369-382, 2012.

[30] R. Crescenzi, A. Rodrigez-Pose, and M. Storper, The Geographical Process behind Innovation: A Europe-United State Comparative Analysis, InstitutoMadrileño de Estudios Avanzados (IMDEA) Ciencias Sociales, 2007.

[31] G. Lindqvist, S. Protsiv, and O. Solvell, Regions, Innovation and Economic Prosperty. Evidence from Europe, Stockholm School of Economics, Stockholm, Sweden, 2008.

[32] D. Libaers and M. Meyer, "Highly innovative small technology firms, industrial clusters and firm internationalization," Research Policy, vol. 40, no. 10, pp. 1426-1437, 2011.

[33] T. Kinnear and J. R. Taylor, Marketing Research: An Applied Aproach, McGraw-Hill, New York, NY, USA, 1996.

[34] A. Bryman and E. Bell, Business Research Methods, Oxford University Press, Oxford, UK, 2nd edition, 2007.

[35] C. Hamilton, Understanding Philosophy for AS Level, Nelson Thornes Ltd, UK, 2003. 

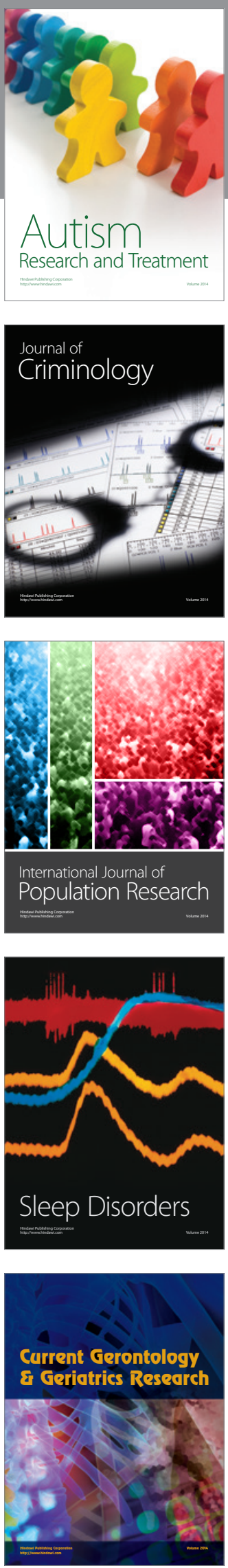
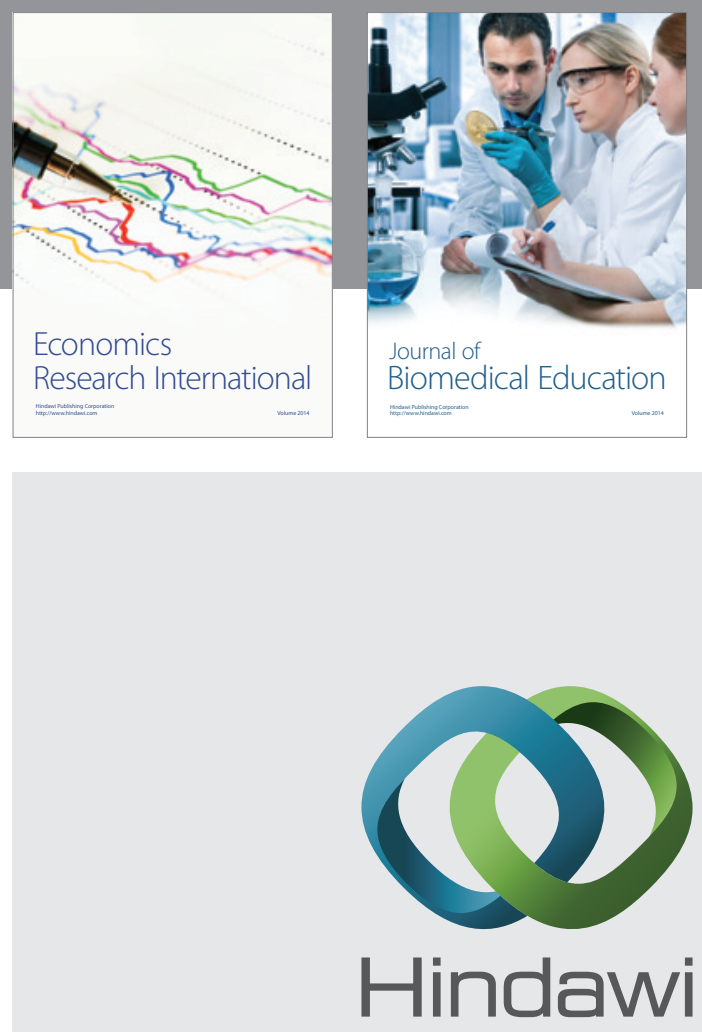

Submit your manuscripts at

http://www.hindawi.com
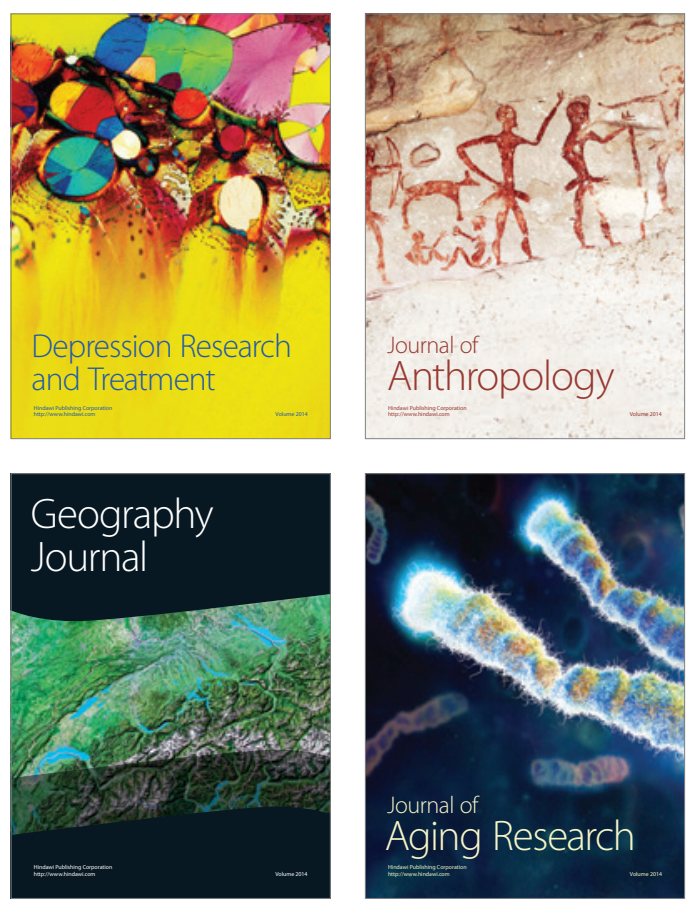
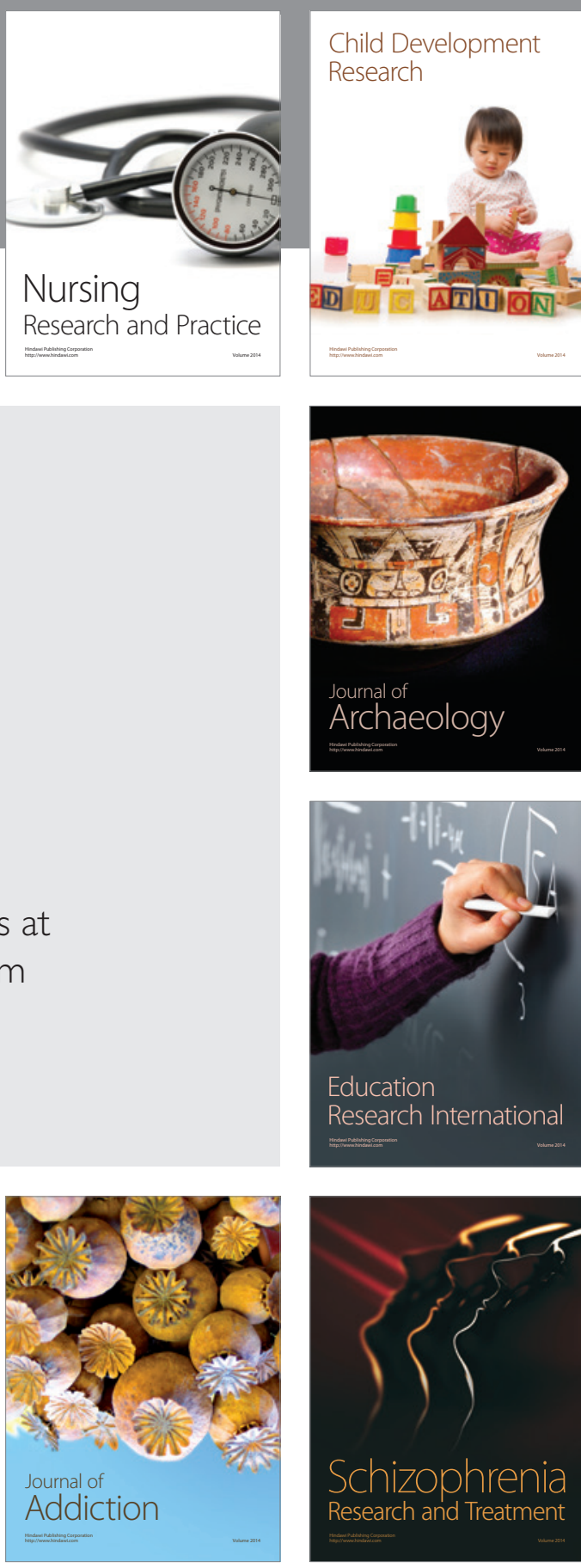

(D)
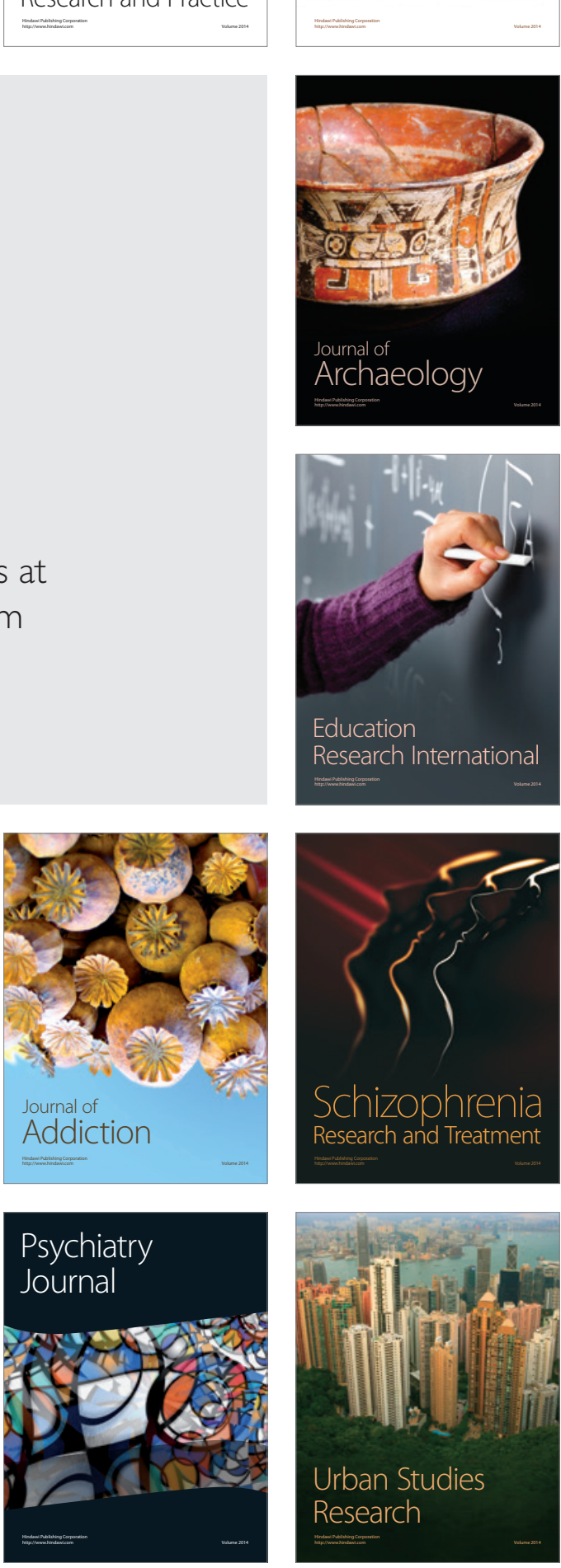